\title{
Qualifying Teachers of English for Specific Purposes to Meet the Global Challenges
}

\author{
Paulus Widiatmoko ${ }^{1}$, Andreas Winardi ${ }^{2}$ \\ ${ }^{1-2}$ Department of English Education, Universitas Kristen Duta Wacana
}

\begin{abstract}
As institutions of higher education prepare graduates to strive for the more competitive job market, teachers of English for Specific Purposes (ESP) play a pivotal role to nurture and facilitate students' English competence for career advancement. It is commonly hypothesized that ESP teachers require more than that of general English instructors are capable of in language teaching-related pedagogy. However, limited numbers of such studies have been conducted in Indonesia as a potentially developing country in the world. This quantitative study aims to portray ESP teachers' perceived qualifications, benefits of the program instruction, and its relevance to meet the challenges of the globalization. Initial findings of this study reveal that almost all of the respondents acknowledged the necessity of ESP teachers to demonstrate capacity in educational principle, language learning theory, Linguistics competence, material and media design, classroom management, intercultural understanding, language assessment, and classroom-based research inquiry. It is perceived that successful ESP teaching is significantly required for graduates to excel the job market, increase professionalism at work, and facilitate the nation competitive edge. Furthermore, ESP programs are considered relevant to meet the present and future challenges of globalization. More elaborative findings will be obtained, specifically addressing difference-variance of perceptions according to respondents' education background and teaching experience.
\end{abstract}

Keywords: ESP teaching, global challenges, teacher competence

\section{INTRODUCTION}

Preparing graduates to win the global job competition is undoubtedly the mission of every higher education institution. Accordingly, skills of the 21 st century prescribe specific competence of career and living in the world. This has urged higher education institutions to enforce various curricular policies. The competency-based curriculum or KBK (KurikulumBerbasisKompetensi)formulation of courses develops learners' hard-skills and soft-skills, or core-discipline subjects and their supporting ones to achieve these objectives. Training, certifications, service learning, apprenticeships, and other programs aim to equip learners with qualifications needed in their future career. KKNI or National Qualification Framework curriculum of higher education ties academic aspect and professional needs even stronger, offering relevance of professional qualification leveling at work with education stages.

In the curriculum of higher education, some courses are offered to support the learners' expertise in their disciplines. Among the courses, one which this study focuses on aims at preparing them for career development and professional life in the future. Dealing with the complexity of language demands in professional situations or workplace, higher education institutions need to have the policy on language teaching and learning in their ESP program.

As ESP programs are addressed for specific needs of discipline or profession, the qualification of its teacher is commonly considered different from that of General English teachers. However, rarely research publications are observed in the context of Indonesia. This study, therefore, aims to: (1) describe competence qualifications expected from teachers of ESP programs and (2) describe how ESP programs are relevant to globalization challenges.

\section{Teacher Competence in ESP}

English for Specific Purposes learning requires some pre-conditions for its effectiveness. First, the relevance between learning process with the future demand of the professions. At this point, one of the objectives of English for Specific Purposes (ESP) is preparing learners' English skills for their future 
professional needs. Dudley-Evans \& John (1998) point out that one of the main concerns of ESP deals with preparing learners to communicate effectively in the tasks prescribed by their study or work situation.Accordingly, Basturkmen (2010, p.8) states that in an ESP situation it is understood that learners would want to achieve 'real world' objectives, the ones requiring specific linguistic competencies. For instance, in English for Medical students, being able to communicate effectively with people from various cultural backgrounds, including from English speaking countries would be an enhancement of their future professionalism. Despite practicing language functions for communication, comprehensive aspects of Medical-related discipline concerning clinical procedures and cross-cultural awareness are supposedly well elaborated. Language development is, therefore, seen as the means to the ends but not as the end in itself.

Secondly, it is necessary to apply teaching methods that provide opportunities and exposures to listen, observe, use, and interact actively using the target language to build learners' language system (language input). Eventually, the use of this language system helps learners to communicate (language output). Ellis (2012) defines input-based instruction as an instruction that "involves the manipulation of the input that learners are exposed to or are required to process" (p.285). One form of input instruction is to manipulate the input in some ways in order to make some target features more noticeable to learners. This input-based instruction usually takes the form of textual enhancement or input enrichment. This technique aims at drawing learners' attention to linguistics target while they are primarily engaged in meaning comprehension. Long et al (1991) conceptualize focus on form as a kind of instruction that "overtly draws students' attention to linguistic elements as they arise incidentally in lessons whose overriding focus is on meaning communication" (pp.4-5). The interest in focus on form instruction (also known as form-focused instruction) was raised in the 1990s as a result of research findings that suggested that exposure to input alone though necessary is not enough and some kind of formal intervention is needed for learners to reach advanced levels of the target like competence.

Renandya (2011) states that input refers to oral or written language that a learner receives that would benefit the language learning process if it meets the following requirements:

a. It has to be comprehensible

b. It has to be abundantly and reliably available

c. It has to be frequently encountered

d. It has to contain language features that are slightly beyond the learners' current level

e. It has to contain language features that engage the learners' attetion

f. It has to be meaningful and interesting

Aside from input-oriented based instruction, there are scholars who opt for more positive and causal role to output in developing the target language system. These proponents do not deny the essential role of input for L2 instruction. However, they reject the view that input alone is sufficient for language acquisition and gives rise to the development of linguistics system (Krashen, 1981; Swain, 1995). Swain (1995, 1985, 2005) outlining her output hypothesis states that output is essential as input in developing L2 knowledge to high levels of target-like precision. Swain (1985) claims that output "pushed" learners from the "semantic processing" required for comprehending the input to the "syntactic" processing" needed for encoding meaning (p.249). Furthermore, Swain (1985) suggests that producing the target language may serve as "the trigger that forces the learners to pay attention to the means of expression needed in order to successfully convey his or her intended meaning" (p.249). One important function of output, among others, according to Swain $(1995,2005)$ is helping learners notice the gap between their linguistic resources and the target language system.

Third, language learning is closely associated with culture learning. Piasecka (2011) exemplifies that learning a language is closely associated with learning the culture. Therefore, revisiting cultural aspects of native speakers speaking the language is considered necessary. It is further proposed that the purposes of learning foreign languages "have evolved from linguistic through communicative to intercultural and intercultural communicative competence" (Piasecka, 2011, p.22). Developing linguistic competence focuses on language as a code, while communicative competence results from interpreting the language as a communication system. Understanding language as a social practice has lead to the emergence of intercultural communicative competence (Scarino, 2010 as cited in Piasecka, 2011).

The above-elaborated pre-conditions of effective ESP instruction require competent teachers in understanding the principles of SLA, the nature of ESP, and how they are applied in the process of language learning.

Qualifying Teachers of English for Specific Purposes to Meet the Global Challenges(Paulus Widiatmoko) 


\section{RESEARCH METHOD}

This study employed a quantitative descriptive method involving 86 respondents, comprising ESP teachers in higher education institutions. They represented the population of teachers from academies and universities in Yogyakarta. The teachers were given a questionnaire consisting of 30 item questions assessing their personal data, the perception of ESP relevance towards globalisations and future challenges, and lastly specific competence of ESP teachers. Likert scale 1-5 denoted their agreement towards the statements. The data was then analyzed descriptively to obtain the respondents' perceptions.

\section{RESULTS AND ANALYSIS}

As Table 1 suggests, it is perceived that successful ESP teaching is significantly required for graduates to excel the job market, increase professionalism at work, and facilitate the nation competitive edge. Furthermore, ESP programs are considered relevant to meet the present and future challenges of globalization. The highest mean is shown in the agreement that ESP program enhances graduates' competitive edge followed by slightly lower means on the other items.

Table 1: Perception of ESP Relevance

\begin{tabular}{clcc}
\hline No & \multicolumn{1}{c}{ Questions } & Mean & Std Dev \\
\hline 12 & Relevance of ESP at present and in the future & 4,77 & 0,412 \\
13. & ESP enhances competitive edge of higher education graduates & 4,82 & 0,39 \\
14. & ESP enhances professionalism of workers at work & 4,68 & 0,501 \\
15. & ESP enhances development of science and other disciplines & 4,55 & 0,555 \\
16. ESP of higher education graduates facilitate the Nation & 4,73 & 0,446 \\
competitiveness & & \\
\hline
\end{tabular}

Table 2.Perception of ESP Teacher Competence

\begin{tabular}{|c|c|c|c|}
\hline No & Questions & Mean & Std Dev \\
\hline 17. & $\begin{array}{l}\text { Teaching ESP requires more competence and knowledge compared to } \\
\text { teaching General English }\end{array}$ & 4,77 & 0,484 \\
\hline 18. & Specific training program is required for ESP teachers & 4,59 & 0,599 \\
\hline 19. & $\begin{array}{l}\text { ESP teachers have to master foundation of foreign/second language } \\
\text { learning }\end{array}$ & 4,59 & 0,523 \\
\hline 20. & $\begin{array}{l}\text { ESP teachers have to master deeper foundation of linguistics compared } \\
\text { to teachers of General English. }\end{array}$ & 4,39 & 0,801 \\
\hline 21. & ESP teachers have to master pedagogic competence & 4,25 & 0,788 \\
\hline 22. & $\begin{array}{l}\text { ESP teachers have to master competence of curriculum and material } \\
\text { design }\end{array}$ & 4,54 & 0,606 \\
\hline 23. & ESP teachers have to be ICT literate & 4,38 & 0,618 \\
\hline 24. & ESP teachers have to be familiar with Psychology of Learning & 4,45 & 0,604 \\
\hline 25. & ESP teachers should be able to manage classes well & 4,69 & 0,466 \\
\hline 26. & ESP teachers should deliver classroom activities interestingly & 4,65 & 0,537 \\
\hline 27. & ESP teachers have to master Cross Cultural Understanding & 4,30 & 0,641 \\
\hline 28. & $\begin{array}{l}\text { ESP teachers should be able to develop language assessment and } \\
\text { testing }\end{array}$ & 4,54 & 0,581 \\
\hline 29. & ESP teachers should be able to conduct classroom based research & 4,25 & 0,691 \\
\hline
\end{tabular}

Findings of this study reveal that almost all of the respondents acknowledged the necessity for ESP teachers to demonstrate capacity in educational principle, language learning theory, Linguistics competence, material and media design, classroom management, intercultural understanding, language assessment, and classroom-based research inquiry. It is interesting to note that the highest mean is on the respondents' agreement towards the necessity of additional training for ESP teachers as compared to the ones teaching general English. The lowest ones, despite not in high range of difference, are on the necessity for ESP teachers to possess competence on classroom action research and to master pedagogic competence. 
As English teaching can be categorized into General English (GE) and English for Specific Purposes/ESP, findings of this study portray how these two programs are related. For this purpose, a discussion of their history is relevant as a starting point. It is argued that the need for ESP teaching is triggered by three main reasons (Hutchinson \& Waters, 1987). First, the world needs new changes or development in science, technology, economy and other technical necessities in the international scale. Second, in relation to Sociolinguistic, there has been a shift from the need to study "traditional" linguistics to the need to study the language for real communication. As a result, there are a lot of variations of the use of English for different communicative purposes. This results in the need for different kind of training to cater for those purposes. The third reason refers more to the study of psychology, Hutchinson \& Waters (1987) emphasize the need to pay more attention to how students learn. In this case, they argue that students use different learning strategies and have different language skills and schemata.

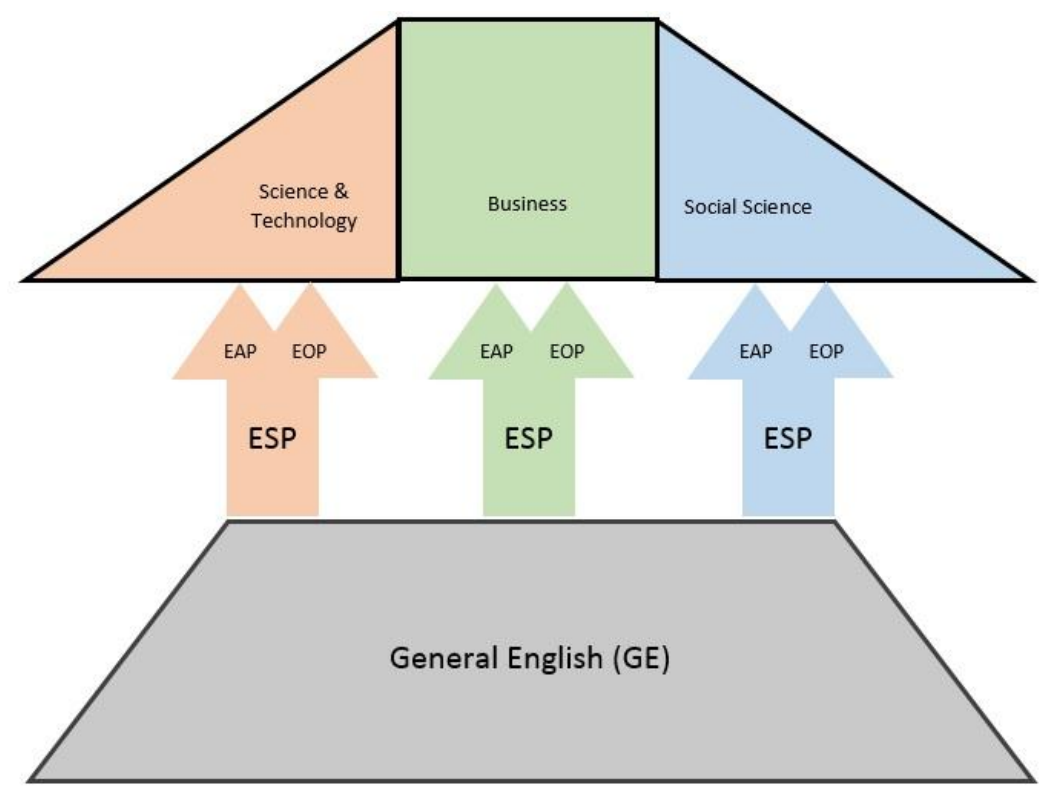

Figure 1. Strategic Roles of GE and ESP

As its purpose to support the development of other fields of study and its use as the medium of professional communication, ESP poses a strategic role of supporting the development disciplines in science and technology, business, and other professional needs (figure 1). It is also undeniable that through ESP programs, graduates of higher education could be prepared to win competitive job market, either through English competence in their disciplines or skills for job selection purposes. Carver (1983) argues that ESP can be classified into English for Academic Purposes (EAP) and English for Occupational Purposes (EOP). EAP equips students with an ability to use English to support them in their fields of study, while EOP aims to equip students with English competence for professional work. The two models of ESP teaching do not place the mastery of English as the ultimate goal, but as a tool to achieve other goals. ESP programs, therefore, could be considered as language practice for the higher level of English use than that of General English. Moreover, every discipline also has specific terminologies or jargons that could have different meanings from general English. The specific discourse of English use in ESP fields presupposes different language expressions and functions that teachers should be familiar with. Therefore, it is argued that ESP teachers should demonstrate ability both in the content areas of the discipline and its Linguistics aspects.

Elaborating the above idea, the teaching of ESP has a very strategic role in improving the competitiveness of university graduates in Indonesia. Their expertise and skills in their field of study completed with good English competence expectedly enable them to interact and communicate actively to support their professional work. With the enforcement of Asian free trade, university graduates in Indonesia face a bigger challenge. This study, therefore, affirms the relevance of ESP towards globalization challenges and that it is necessary to prepare competent ESP teachers so as to facilitate students' achievement of the 
program goals, enabling them to win the competitive job market, to be professional workers, and ultimately bring a competitive edge to the nation.

\section{CONCLUSION}

Globalization as a shared challenge should be considered as an opportunity to excel expertise in any field of discipline, including English as one of the languages that "connect" the world. Acknowledgment by respondents of this study for English to serve professional and academic purposes, more than commondaily language functions, presupposes competent teachers being able to demonstrate ability in educational principle, language learning theory, Linguistics competence, material and media design, classroom management, intercultural understanding, language assessment, and classroom-based research inquiry. These initial findings expectedly could be extended into the formulation of the model for ESP teacher training and professional development.

\section{REFERENCES}

Basturkmen, H. (2010). Developing courses in English for specific purposes. New York: Springer.

Carver, D. (1983). Some propositions about ESP. The ESP Journal, 2(2), 131-137.

Dudley-Evans, T., \& John, M. S. (1998). Developments in English for specific purposes: A multidisciplinary approach. Cambridge: Cambridge University Press.

Ellis, R. (2012). Language teaching research and language pedagogy. West Sussex: John Wiley \& Sons.

Hutchinson, T., \& Waters, A. (1987). English for specific purposes. Cambridge: Cambridge University Press.

Krashen, S. (1981). Second language acquisition and second language learning. Oxford: Oxford University Press.

Long, M. (1991). A design feature in language teaching methodology. In K. De Bot, R. Ginsberg, \& C. Kramsch (Eds.). Foreign language research in cross-cultural perspectives (pp. 39-52). Amsterdam: Benjamins.

Piasecka, L. (2011). Sensitizing foreign language learners to cultural diversity through developing intercultural communicative competence. In Aspects of culture in second language acquisition and foreign language learning (pp. 21-33). Berlin: Springer.

Renandya, W. (2011). "Teacher, the tape is too fast!'Extensive listening in ELT. ELT Journal, 65(1), 5259.

Swain, M. (1985). Communicative competence: Some roles of comprehensible input and comprehensible output in its development. Springer Berlin Heidelberg., 15, 165-179.

Swain, M. (1995). Three functions of output in second language learning. In G. Cook \& B. Seidlhofer (Eds.). Principle and practice in applied linguistics: Studies in honor of H. G. Widdowson (pp. 97114). Oxford: Oxford University Press.

Swain, M. (2005). The output hypothesis: Theory and research. In E. Hinkel (Ed.), Handbook on research in second language teaching and learning (pp. 471-483). New York and London: Routledge 